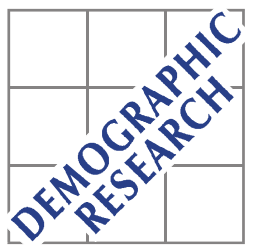

Demographic Research a free, expedited, online journal of peer-reviewed research and commentary in the population sciences published by the Max Planck Institute for Demographic Research Konrad-Zuse Str. 1, D-18057 Rostock · GERMANY www.demographic-research.org

DEMOGRAPHIC RESEARCH

VOLUME 25, ARTICLE 16, PAGES 513-544

PUBLISHED 23 AUGUST 2011

http://www.demographic-research.org/Volumes/Vol25/16/

DOI: 10.4054/DemRes.2011.25.16

Research Article

\title{
The interplay of employment uncertainty and education in explaining second births in Europe
}

\section{Alicia Adsera}

\section{(C) 2011 Alicia Adsera.}

This open-access work is published under the terms of the Creative Commons Attribution NonCommercial License 2.0 Germany, which permits use, reproduction \& distribution in any medium for non-commercial purposes, provided the original author(s) and source are given credit.

See http:// creativecommons.org/licenses/by-nc/2.0/de/ 


\section{Table of Contents}

$\begin{array}{lll}1 & \text { Introduction } & 514\end{array}$

$2 \quad$ Fertility and the European labor market during the 1990s 516

$3 \quad$ Second births across European countries $\quad 522$

3.1 Data and method 522

$\begin{array}{lll}3.2 & \text { Results } & 524\end{array}$

$4 \quad$ Second births in Spain $\quad 529$

$4.1 \quad$ Data and method $\quad 529$

$\begin{array}{lll}4.2 & \text { Results } & 531\end{array}$

5 Discussion: Employment uncertainty and education 537

$\begin{array}{lll}6 & \text { Acknowledgements } & 539\end{array}$

$\begin{array}{ll}\text { References } & 540\end{array}$

$\begin{array}{ll}\text { Appendix } & 544\end{array}$ 


\title{
The interplay of employment uncertainty and education in explaining second births in Europe
}

\author{
Alicia Adsera ${ }^{1}$
}

\begin{abstract}
This paper analyzes how labor market instability since the late 1980s in Europe has mediated decisions to have a second child. In particular, I seek to determine the dimensions of economic uncertainty that affect women with different educational backgrounds. First, employing time-varying measures of aggregate market conditions for women in 12 European countries, as well as micro-measures of each woman's labor market history, I find that delays in second births are significant in countries with high unemployment and both among women who are unemployed, particularly the least educated, and those who have temporary jobs. Holding a very short contract is shown to be more critical than unemployment for college graduates. Second, using the 2006 Spanish Fertility Survey, I present remarkably similar findings for Spain, the country with the most dramatic changes in both fertility and unemployment in recent decades: a high jobless rate and the widespread use of limited-duration contracts are found to be correlated with a substantial postponement of second births.
\end{abstract}

\footnotetext{
${ }^{1}$ Woodrow Wilson School, Princeton University, 347 Wallace Hall, Princeton NJ 08544.

E-mail: adsera@princeton.edu.
} 


\section{Introduction}

Since the late 1980s, European fertility rates have plummeted, particularly in Southern Europe and in German-speaking countries, where rates have fallen to 1.3 or lower in recent years (Kohler, Billari, and Ortega 2002). As has been shown by an extensive body of literature, this general trend has resulted from changes in preferences for small families, family planning, and the demands of dual careers (Becker 1981, Lesthaeghe and Surkyn 1988; Galor and Weil 1996, Bongaarts 2002). The cross-country variation in fertility has been attributed to the nature of the welfare state and its social policies (Esping-Andersen 1999; Gauthier 2007; Andersson, Kreyenfeld, and Mika 2009) and to differences in economic uncertainty (Blossfeld et al. 2005; Kohler, Billari, and Ortega 2002; Adsera 2005, 2011; Sobotka, Skirbekk, and Philipov 2010), among others factors. An additional mechanism leading to the decrease in completed fertility has been delayed motherhood: older mothers are less likely to attain their intended number of children (Morgan 2003). Since the levels of childlessness have not increased much in Europe, and since there are still substantial fertility differences across countries once differential postponement has been taken into account (Sobotka 2004), a better understanding of the variation in second births is warranted. Figure 1 presents the nonparametric estimates of the survivor function of transitions to second births among women in several European Union countries during the 1990s. Cross-country variations in the timing of the second birth are considerable. Women in Portugal, Spain, and Italy are the least likely to have had a second child: five years after their first birth, about $60 \%$ have not delivered another baby. By contrast, only around $25 \%$ of Finish and Dutch women have not had a second child.

This paper examines the role that economic conditions played in the decisions of women to have more than one child during this time. During the period of analysis, the European labor market was characterized by cycles of high and persistent unemployment, and by an upward trend in the share of temporary employment. In addition to looking at how both the lack of work and some insecurity in a job currently held shaped the choices of women in general, the paper also explores the extent to which labor market instability may relate differently to transitions to a second birth among women with different educational backgrounds.

To this end, the paper undertakes two types of analysis. First, I employ the 19942000 waves of the European Community Household Panel (ECPH) for women in 12 European countries to estimate proportional hazard models of second births. The estimations include time-varying measures of aggregate labor market conditions, as well as micro-measures of each woman's labor market history, employment characteristics, and earnings. Second, I employ the 2006 Spanish Fertility Survey to show how those economic conditions-i.e., provincial unemployment and share of 
temporary employment-faced by women, either as they entered the labor market in their early twenties or after the birth of their first child, are connected to the timing of second births. I chose to analyze the results of that survey because Spain was the OECD country that experienced the most dramatic changes in both fertility and unemployment rates in recent decades. Our findings indicate that both individual and aggregate unemployment, as well as temporary employment, were positively associated with a delay in second births among all women, regardless of their educational backgrounds. In addition, two other results stand out. First, unemployment slowed down childbearing plans, particularly among the least educated, whereas its impact was minor among college graduates. Second, short-term contracts (or a labor market with a high proportion of temporary jobs) seemed to have had a particularly negative effect among the most educated women, compared to that of unemployment.

\section{Figure 1: Non-parametric estimates of transitions to second birth (ECHP 1994-2000)}

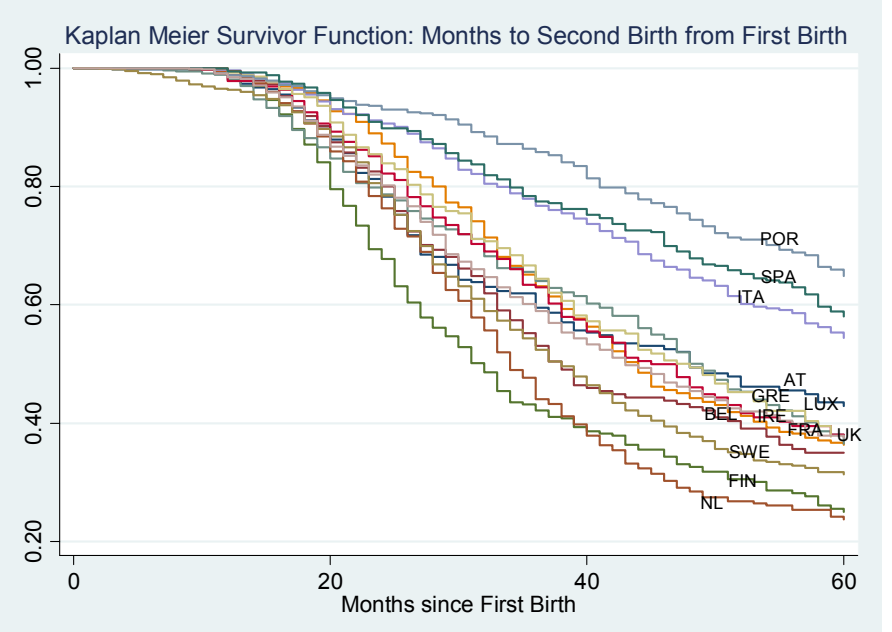

Note: Kaplan Meier survivor function of transitions to second births among women in European countries who had a first birth in 1992 or after. Data come from European Community Household Panel 1994-2000.

The paper is organized as follows. Section 2 reviews the main changes in economic instability in Europe since the mid-1980s, and explores the possible mechanisms through which economic conditions affect women's decisions to have a second child. Section 3 describes the data and methodology employed in the panel of mothers of 12 European countries during the 1990s, and presents results from Cox 
proportional hazard models of transitions to second births. Section 4 examines the estimations conducted with the 2006 Spanish Fertility Survey, and includes the simulated proportion of women of different educational levels with a second child under various economic scenarios. Section 5 provides a general discussion of the joint effects of educational achievement and economic uncertainty on the transition to second births in Europe.

\section{Fertility and the European labor market during the 1990s}

Fertility behavior is the result of forward-looking and sequential decisions that individuals (or households) make in an uncertain environment under multiple institutional and economic constraints. Economic events not only alter a couple's current demand for children, but also their predictions of future constraints, and, hence, of future demands (Butz and Ward 1980; Ermisch 1988). ${ }^{2}$

The economic environment in which household formation and childbearing decisions were made was anything but certain in some European countries during the 1990s. European unemployment went up from under 3\% before 1975 to about $10 \%$ in the $1990 \mathrm{~s}$. The average female unemployment rate rose from $2.5 \%$ in 1970 to $6.5 \%$ in 1980 , and then to around $11 \%$ from the mid-1980s to the late 1990 s. Table 1 shows that female unemployment rates in 1998 ranged from $21.1 \%$ and $15.4 \%$ in Spain and Italy, to moderate levels of around $4 \%$ to $6 \%$ in Luxembourg, the United Kingdom, the Netherlands, and Denmark.

Although the impact of the regulatory environment on the level of unemployment is still debated, there is some evidence that highly regulated markets were hostile environments for young workers (see Addison and Teixeira 2003 for a review). Bertola, Blau, and Kahn (2002) have noted that areas with high employment protection, such as Southern Europe, had lower unemployment rates of prime-aged men than of young and female workers. Female unemployment rates, for example, climbed beyond $15 \%$ in Greece and Italy, and to over $20 \%$ in Spain by the mid-1990s, or about seven to 12 points higher than the jobless rates of their male counterparts (Azmat, Guell, and Manning 2006). To make matters worse, European unemployment during this period was, on average, very persistent. In 1990, around $50 \%$ of those unemployed in the

\footnotetext{
${ }^{2}$ A large set of studies has unveiled significant relationships between the economic environment, fertility, and its timing in many Western nations, such as the U.S. (Butz and Ward 1980), Britain (De Cooman, Ermisch, and Joshi 1987; Ermisch 1988; Murphy 1992), Italy (Aassve, Billari, and Ongaro 2001) Spain (Ahn and Mira 2001, Gutierrez-Domenech 2008), Sweden (Hoem and Hoem 1989; Hoem 2000), Norway (Kravdal 2002), Germany (Kreyenfeld 2009), and Europe (Adsera 2005; 2011), among others.
} 
European Union had been out of work for more than 12 months. Long-term unemployment delayed household formation (and with it, childbearing) in countries such as Italy or Spain (Aassve, Billari, and Ongaro 2001; Gutierrez-Domenech 2008). Of all the European countries, the level and the persistence of unemployment was exceptionally severe in Spain. As shown in Figure 2, the Spanish unemployment rate moved up from around $2 \%-3 \%$ during the early 1970 s to $20 \%$ by the mid- 1980 s, and it stayed at this level throughout the 1990s. The rate of unemployment for young women (aged 20-24) reached almost 50\% in the mid-1980s, and again in the 1990s (Figure 2). During the same period, Spain experienced the largest decline in fertility in Europe. The Spanish total fertility rate moved from around 2.8 in 1972 to under 1.3 from the mid1980 s onwards. The rate was still around 1.2 in 2000 , only to move up to 1.4 by the end of the decade (Figure 2).

Table 1: Female unemployment rates, share of workers with contracts of limited duration and their satisfaction in Europe in the 1990s

\begin{tabular}{lccc}
\hline & $\begin{array}{c}\text { Female Unemployment } \\
\text { (a) }\end{array}$ & $\begin{array}{c}\text { Contracts Limited } \\
\text { Duration }{ }^{(\mathbf{b})}\end{array}$ & $\begin{array}{c}\text { Relative Satisfaction job } \\
\text { security }\end{array}$ \\
\hline Austria & 5.4 & 7.9 & 84.5 \\
Belgium & 11.6 & 8.2 & 74.6 \\
Denmark & 6.0 & 9.9 & 72.6 \\
Finland & 12.0 & 17.4 & 66.3 \\
France & 12.8 & 13.9 & 61.3 \\
Germany & 9.4 & 12.4 & 82.7 \\
Greece & 16.8 & 12.5 & 57.1 \\
Ireland & 7.3 & 7.2 & 64.9 \\
Italy & 15.4 & 8.6 & 62.1 \\
Luxembourg & 4.0 & 4.9 & 77.9 \\
Netherlands & 5.0 & 13.0 & 73.5 \\
Portugal & 6.2 & 17.2 & 71.5 \\
Spain & 21.1 & 33.0 & 63.6 \\
Sweden & 8.0 & 16.1 & n.a. \\
United Kingdom & 5.3 & 7.3 & 74.3 \\
EU 15 & 10.7 & 13.0 & 70.5 \\
\hline
\end{tabular}

Source: (a) \& (b) Data are 1998 from EUROSTAT http://epp.eurostat.ec.europa.eu/. (c) Ratio of average satisfaction of temporary to permanent workers calculated using ECHP wave 4 data (1996), OECD Employment Outlook (2002).

In the standard microeconomic model of fertility, the reduction in the opportunity cost of time devoted to children (forgone wages) associated with an unemployment spell is expected to boost fertility (Becker 1981; Galor and Weil 1996). However, if the negative income effect from reduced work earnings is sufficiently large, unemployment 
may lead to a baby bust. The point in life when unemployment episodes occur, and how long they (are expected to) last, matter in determining their ultimate impact on fertility. If unemployment is high and persistent, young women (with less labor market experience on average) may fear that time spent in childbearing (including any maternity leave they might be eligible to take) may harm their likelihood of reemployment or increase their risk of future unemployment, and, as a result, hurt their lifetime wage-growth and benefits. Women may choose to postpone maternity to secure their present position or to send a signal of career commitment to their prospective employers. Furthermore, persistent aggregate unemployment may alter the childbearing plans not only of those directly affected by it, but also of those to whom it constitutes a threat, as documented, for example, for the interwar period and the 1930s depression (Becker 1981; Murphy 1992). For recent years, Kravdal (2002) has found the effect of unemployment at the municipality level in Norway to be more important than individual unemployment shocks for higher order birth rates. In Spain, Ahn and Mira (2001) and Gutierrez-Domenech (2008) have shown that increases in total male and female unemployment rates were associated with a significant postponement of first births, and, in general, of family formation.

\section{Figure 2: Fertility, unemployment, and fixed-term contracts in Spain,} 1972-2006

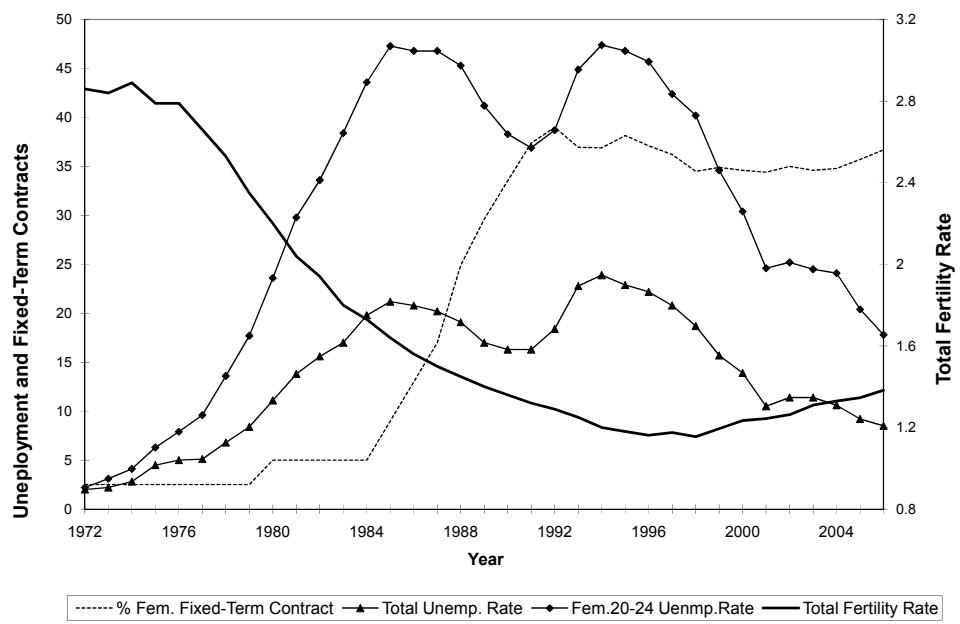


In addition to high unemployment rates, European labor markets witnessed a strong increase in the share of employees with non-permanent contracts. Permanent contracts (based on high firing costs and generous severance payment schemes borne by the employer) were the norm in European countries well into the early 1980s. Temporary work was mainly used for short probation periods (after which the contract became permanent) and for workers under replacement contracts (used to substitute workers on leave for reasons such as sickness and maternity). Firms used fixed-term contracts to adjust to the business or seasonal cycle, or for training purposes (Booth, Dolado, and Frank 2002). However, precarious short-term contracts proliferated starting in the mid-1980s after several partial labor reforms eased existing protective regulations in an attempt to reduce unemployment, particularly among the young in Southern Europe (Booth, Dolado, and Frank 2002; OECD 2004).

As shown in Table 1, column (2), in 1998 13\% of European workers held temporary contracts (as defined by EUROSTAT). Spain, which introduced nonpermanent contracts in 1984, and encouraged their use with temporary subsidies for new hires, had the highest rate: one out of three workers was employed under a contract of limited duration. Among women, that proportion rose from about 5\% in 1984 to over $35 \%$ in less than 10 years (Figure 2). Although the proportion of temporary contracts was particularly high in Southern Europe, Finland and Sweden also employed them, mostly for highly cyclical jobs (Holmlund, Kolm, and Storrie 2002). ${ }^{3}$

Temporary contracts were especially concentrated among young and unskilled workers (OECD 2002). In 2000, one in four 15-to-24-year-old workers held a temporary contract (Table 2, column (1)). In some countries, the ratio was much higher: one in two for Finland and two in three in Spain. By contrast, among 25-to-54-year-old workers, only $8 \%$ had temporary contracts in the OECD. Still, the Spanish rate stood at $25 \%$, and even though the total percentage of 25-to-54-year-old workers who held a non-permanent contract was lower than that of the younger group, they constituted $54.3 \%$ of all workers with temporary contracts in the OECD. While $16 \%$ of the least educated held temporary contracts, just under $10 \%$ of the highly educated were working under non-permanent contracts. In Spain, the percentages were $36.6 \%$ and $26.2 \%$, respectively. Again, even though the least educated were more likely to have been in vulnerable positions, one in five of all temporary workers had tertiary education. In Spain, Italy, Finland, and Sweden the share was one in four or higher.

\footnotetext{
${ }^{3}$ Temporary employment also rose in Italy during the late 1980s and the 1990s as employers were searching for ways to reduce non-wage costs, and in many cases took the form of informal continuous agreements whereby employees would file taxes as self-employed though they would effectively work within a firm. Some of those jobs are not counted under the EUROSTAT definition.
} 
Table 2: Characteristics of temporary employment across Europe, 2000

\begin{tabular}{|c|c|c|c|c|c|c|c|}
\hline & \multicolumn{5}{|c|}{ (\%) Temporary in total employment for the group } & \multicolumn{2}{|c|}{$\begin{array}{c}\text { (\%)of all Temporary } \\
\text { workers }\end{array}$} \\
\hline & \multicolumn{2}{|c|}{ Age } & \multicolumn{3}{|c|}{ Education } & \multirow{2}{*}{$\begin{array}{c}\text { Age } \\
25-54\end{array}$} & \multirow{2}{*}{$\begin{array}{c}\text { Education } \\
\text { High }\end{array}$} \\
\hline & $15-24$ & $25-54$ & Low & Medium & High & & \\
\hline Austria & 28.2 & 3.8 & 21.9 & 4.2 & 5.7 & 38.9 & 10.3 \\
\hline Belgium & 19.7 & 4.5 & 10.3 & 8.7 & 8.1 & 59.2 & 30.2 \\
\hline Denmark & 30.6 & 6.5 & 18.9 & 8.5 & 5.9 & 40.8 & 14.5 \\
\hline Finland & 49.5 & 14.3 & 17.9 & 20.5 & 13.9 & 66.5 & 27.7 \\
\hline France & 34.8 & 6.6 & 16.3 & 15.2 & 13.0 & 54.3 & 22.1 \\
\hline Germany & 38.9 & 6.1 & 29.5 & 9.2 & 9.1 & 41.0 & 16.8 \\
\hline Greece & 28.4 & 12.1 & 17.7 & 12.1 & 9.4 & 67.3 & 18.5 \\
\hline Ireland & 15.1 & 5.7 & 11.5 & 8.4 & 8.1 & 48.9 & 26.7 \\
\hline Italy & 14.7 & 5.4 & 10.2 & 9.6 & 11.3 & 63.1 & 13.6 \\
\hline Luxembourg & 11.3 & 1.8 & 3.2 & 3.7 & 2.9 & 43.3 & 17.4 \\
\hline Netherlands & 24.3 & 6.9 & 17.1 & 11.7 & 10.2 & 50.8 & 20.0 \\
\hline Portugal & 34.4 & 10.9 & 19.4 & 24.0 & 20.6 & 52.1 & 12.3 \\
\hline Spain & 67.4 & 25.2 & 36.6 & 29.5 & 26.2 & 60.4 & 24.2 \\
\hline Sweden & 41.3 & 10.5 & 17.9 & 14.0 & 13.4 & 60.8 & 28.6 \\
\hline United Kingdom & 12.0 & 4.9 & 5.3 & 6.0 & 8.9 & 53.8 & 38.6 \\
\hline OECD & 25.0 & 8.0 & 15.7 & 10.4 & 9.3 & 54.3 & 20.5 \\
\hline
\end{tabular}

Note: Education levels: low refers to ISCED 0/1/2, medium refers to ISCED 3 and high refers to ISCED 5/6/7.

Source: OECD Employment Outlook (2002)

Workers with contracts of limited duration received less formal employer-provided training (OECD 2002) and had lower wages than similar workers under permanent contracts (around 16\% lower for men and 13\% for women in Britain, and around 10\% lower in Spain and 20\% in France) (Booth, Francesconi, and Frank 2002 for Britain; Dolado, García-Serrano, and Jimeno 2002 for Spain; Blanchard and Landier 2002 for France). Access to fringe benefits - such as paid vacations, paid sick leave, maternity leave, unemployment insurance, and pension schemes - was more precarious among temporary-contract workers. Although conditions vary across countries, most nations impose minimum contributory periods that almost certainly harm those holding contracts of limited duration. ${ }^{4}$ Temporary contracts are generally correlated with higher

\footnotetext{
${ }^{4}$ For detailed information on contributory periods and levels of benefits, see OECD 2002. By way of example, maternity leaves required a minimum contributory period ranging from three days in Denmark to six
} 
levels of job turnover and multiple spells of unemployment (Saint-Paul 2000; Blanchard and Landier 2002). Overall, temporary workers in Europe are consistently less satisfied with their job security than those with permanent positions. In the period from 1996 to 2002, the ratio of average satisfaction of temporary to permanent workers averaged $70 \%$ in OECD countries, ranging from $57 \%$ in Greece and less than $64 \%$ in France, Italy, and Spain to almost $85 \%$ in Austria (Table 1, column (3)). The combination of lower earnings, reduced social benefits, and more job rotation might have affected long-run fertility choices. Indeed, Adsera (2006) showed that, after taking into account aggregate unemployment as well as demographic and job differences, Spanish women in temporary employment fell short of achieving their desired fertility during the $1990 \mathrm{~s}^{5}$

Even though unemployment and temporary contracts may have affected fertility plans across the board, their impact was probably mediated by the level of education of each woman. First, women of different educational backgrounds may search in separate labor markets and for different types of positions. Unemployment rates within European countries were generally lower for the highest educated than for those with less than secondary schooling. Second, women with higher levels of education might have been able to smooth income shocks, either because they had more savings or because they had access to the earnings of a better-employed partner. These factors may have allowed them to wait for (and aim at) a better job match or a permanent position. By contrast, less educated women were more budget constrained, in immediate need of work, and less confident about obtaining a permanent position in the near future. Third, the degree of selection of women who have already become mothers may be different across skill levels. Highly skilled women who are committed to their careers may postpone maternity until they secure a proper position. ${ }^{6}$ As a result, the average highly educated working mother in our sample may have been in a better bargaining position, or have been more sheltered in a difficult labor market, than some of her peers.

months in Portugal and 26 weeks in the United Kingdom. In Spain, maternity benefits are received for 16 weeks, and the current minimum contributory period is 180 days in the last seven years (shorter for very young mothers). Slightly longer contributory periods are needed to receive unemployment benefits.

${ }^{5}$ Speder and Kapitany (2009) also found that adverse employment conditions limit the realization of fertility intentions in Hungary.

${ }^{6}$ Kreyenfeld (2009) found that, among Eastern and Western German women, the highly educated are the most inclined to postpone first births when subject to employment uncertainties and concerns about the security of their jobs. 


\section{Second births across European countries}

\subsection{Data and method}

The first part of the paper uses the 1994-2000 waves of the European Community Household Panel Survey (ECHP) across 12 European Union member states (Austria, Belgium, Finland, France, Greece, Ireland, Italy, Luxembourg, the Netherlands, Portugal, Spain, and the United Kingdom). The dataset provides both the year and the month of birth for each individual in the household. With this information, it is possible to reconstruct backwards the childbearing history of women. To minimize the exclusion of children who had already left the household, the sample includes only women who were 40 years old or younger at the time of their first interview. ${ }^{7}$ The results are robust to restricting the sample to women aged 38 and younger. Further, in the data, less than $0.7 \%$ of children lived with their father and not their mother, so this is not likely to bias the results in any important manner.

I estimate Cox proportional hazard models of the transition to second births. The dependent variable is months to a birth from the first birth. For each woman $i$ in country $c$ and month $y$ who has her first birth at time $t=0$, the (instantaneous) hazard ratio function at $t>0$ is assumed to take the proportional hazards form:

$$
\lambda_{i c v t}=\lambda_{0}(0) \exp \left(x_{i c v t}^{\prime} \beta+m_{c(y-12)} \delta+w_{i c(y-7) t} \mu+C+T+M\right)
$$

where $\lambda_{0}(\mathrm{t})$ is the baseline hazard function, $x_{i c y t}$ is a vector of demographic differences between individuals, $m_{c(y-12)}$ is a vector of 12-month lagged aggregate economic conditions in country $c$, and $w_{i c(y-7) t}$ is a vector of seven-month lagged individual labor market status and work income. To account for country unobservables, and given that unemployment rates within each country offer sufficient variation over time, I include a vector of country fixed effects, $C$, to analyze within-country changes in the timing of fertility as a response to changing economic conditions. ${ }^{8}$ The specification also includes a vector of year dummies, $T$, to account for world business cycles/shocks; and a vector

\footnotetext{
${ }^{7}$ Unfortunately, because the survey does not provide complete retrospective fertility history, we cannot account for children who have died. However, in the European context, we expect this number to be small. ${ }^{8}$ The cross-country variation in labor market characteristics is greater than the within-country, so excluding country dummies is likely to result in more precise estimates. However, because there may be omitted country-specific factors that are correlated with labor market characteristics and fertility, estimates using cross-country variation may be confounded. The use of within-country variation by adding country dummies to account for unobservables addresses this source of confounding, but at the expense of losing some variation (precision).
} 
of monthly dummies, $M$, to account for any seasonality in births. I use a grouped robust variance as estimated by Lin and Wei (1989), and cluster the errors by duration since exposure (that is, from the time elapsed since the individual entered the sample) to take into account the time frame of the sample, and to avoid underestimating the errors. The results are robust to, alternatively, clustering by country.

All estimates contain basic demographic controls, $x_{i c y t}^{\prime}$ birthplace age at first birth, the sex of the first child, as well as time-varying marital status (single, married, or cohabiting), and each woman's education (and her partner's, if present). The education categories include less than upper secondary, upper secondary, and tertiary education.

In addition, I link each woman-monthly observation to the unemployment level and other aggregate conditions prevailing in her country of residence one year ago $\left(m_{c(y-12)}\right)$. Country-level covariates include female unemployment rates, share of public sector (and its square), index of maternity benefits, and log of GDP per capita. Labor market and income per capita series are obtained from OECD Labour Force Statistics, OECD Economic Outlook and national official statistics. I construct a maternity benefits index using the Social Security Programs throughout the World ${ }^{9}$, and Employment Outlook (OECD, various issues). Unemployment rates are monthly, whereas the other series are annual.

Finally, models include longitudinal information on the labor market status of each woman. The ECHP contains data on the labor market situation of the individual for both the year of the interview and the previous year, unemployment episodes during the five years prior to each interview, the first job the individual ever had, as well as the dates when the current job started and the last job ended. Since interviews for the first wave of the panel were conducted in either 1993 or 1994, the earliest year for which there is any complete individual labor market information is 1992. To capture labor market conditions from the moment they become mothers, the sample includes women who had their first child on January 1992 or later. The final sample contains data on 6,920 women with 2,842 observed births by 2001 , and its size per country across years is fairly stable. Around $6 \%$ of the individuals were lost in each interview, but a similar percentage were added from new mothers and the new survey. For those who were lost before a new birth occurred, the observation is censored at the date of the last available interview. The sample appears to be resilient to potential biases from its panel nature and attrition. ${ }^{10}$

\footnotetext{
${ }^{9}$ Index was compiled from various volumes of this publication of the US Department of Health and Human Services, 2002-2010.

${ }^{10}$ Several studies have found that attrition biases in the ECHP are relatively mild and low for individuals living in couples, as were the great majority in this sample (Nicoletti and Peracchi 2002, Ehling and Rendtel 2004).
} 
Since women may change their employment status immediately before or after giving birth, I lag all time-varying employment and income covariates by seven months $\left(w_{i c(y-7) t}\right)$ to reduce any reverse causality problem. Nonetheless, this problem is not as serious for second births as it is for transitions to maternity, since most employment reallocations generally occur around the first birth (Browning 1992). The results are robust to using seven- to 12-month lags (and estimates are available upon request). I chose the seven-month lag because it affords a large sample size, and it is early enough that major changes in employment induced by the pregnancy itself were unlikely to have taken place.

In particular, the specification includes covariates of the employment status of the woman (employed, unemployed, or inactive), as well as work earnings, both from the woman and from her partner (if present). Among those who were employed, the following job characteristics are considered: full- or part-time (30 hours and less), employed or self-employed, and the sector of employment (public or private). ${ }^{11}$ In addition, the ECHP contains information on the length of the woman's contract if employed. Using this information, I construct two separate variables to characterize contracts that are not permanent.

1. Non-Permanent Contract (=1): whenever the woman declared her contract was not permanent, regardless of its length.

2. Very Short Contract $(=1)$ : among employed women with no permanent contract, it includes both those with casual work or no contract, plus those with fixed-term contracts with a duration of less than a year.

\subsection{Results}

Tables 3 and 4 present the results for the European panel. In addition to the general information on the individual labor market status and type of employment, each table includes one of the measures of contract length defined above: in Table 3, whether the contract was permanent or not; and in Table 4, whether the contract was of very short duration. Models are first estimated jointly for all women in the 12 countries, then separately for each educational group, and, finally, in a sample restricted to Southern European countries (Spain, Italy, Portugal, and Greece), which experienced the largest hikes both in unemployment and in temporary employment across Europe.

In line with the expectation that working women trade off having children in favor of less time-demanding alternatives (Becker 1981), all of the specifications show that

\footnotetext{
${ }^{11}$ Estimates are robust to the inclusion of information on the employment conditions of the partner, if present.
} 
active mothers, on average, experience substantially slower transitions to second births than women who remain inactive. Among those who participate in the labor market, there are large differences depending on their sector and hours of employment, even though earnings for each woman (and her partner) are kept constant in all specifications. Women working full-time in the private sector have the lowest estimated hazard of having a second child (almost $20 \%$ lower than inactive women on average). The difference is particularly large among the least educated. Working in the public sector, as opposed to the private sector; and working part-time, as opposed to full-time; are positively associated with second births. On average, the hazard of having a second birth among those employed part-time in the public sector is over $25 \%$ higher than that of stay-at-home mothers. Public employment seems to provide favorable conditions for combining work and children across all educational groups, while for those with tertiary education (who may be less inclined to abandon the labor market), access to part-time work matters the most. Additionally, high-skilled women may have achieved greater bargaining power at their current jobs to request part-time positions than those in more menial occupations.

Table 3: Transition to second births, employment conditions and non-permanent contracts in Europe (ECHP 1994-2000)

\begin{tabular}{|c|c|c|c|c|c|}
\hline & $\begin{array}{l}\text { (1) } \\
\text { All }\end{array}$ & $\begin{array}{c}(2) \\
\text { Low } \\
\text { Educated }\end{array}$ & $\begin{array}{c}\text { (3) } \\
\text { Mid } \\
\text { Educated }\end{array}$ & $\begin{array}{c}\text { (4) } \\
\text { High } \\
\text { Educated }\end{array}$ & $\begin{array}{c}(5) \\
\text { Southern } \\
\text { Europe }\end{array}$ \\
\hline \multicolumn{6}{|l|}{ Demographics } \\
\hline \multirow[t]{2}{*}{ Foreign-Born } & -0.084 & $-0.327^{\star}$ & -0.099 & 0.299 & 0.179 \\
\hline & $(0.84)$ & $(2.09)$ & $(0.59)$ & $(1.45)$ & $(1.11)$ \\
\hline \multirow[t]{2}{*}{ Non-EU-Born } & 0.049 & $0.569^{*}$ & 0.092 & -0.341 & 0.071 \\
\hline & $(0.33)$ & $(2.32)$ & $(0.36)$ & $(1.15)$ & $(0.30)$ \\
\hline \multirow[t]{2}{*}{ Age at First Birth } & $-0.047^{* *}$ & $-0.049^{* *}$ & $-0.047^{* *}$ & $-0.045^{\star *}$ & $-0.033^{* *}$ \\
\hline & $(9.22)$ & $(5.80)$ & $(6.11)$ & $(3.76)$ & $(4.79)$ \\
\hline \multirow[t]{2}{*}{ First Boy } & -0.034 & -0.036 & -0.052 & -0.016 & 0.002 \\
\hline & $(1.01)$ & $(0.49)$ & $(0.77)$ & $(0.24)$ & $(0.03)$ \\
\hline \multirow[t]{2}{*}{ Married } & $0.527^{\star \star}$ & $0.376^{\star *}$ & $0.610^{* *}$ & $0.624^{\star *}$ & $0.876^{* *}$ \\
\hline & $(7.28)$ & $(2.68)$ & $(5.11)$ & $(4.12)$ & $(3.36)$ \\
\hline \multirow[t]{2}{*}{ In a Couple (Married or not) } & 0.617 & $1.648^{*}$ & 0.034 & -0.028 & -0.290 \\
\hline & $(1.56)$ & $(2.36)$ & $(0.07)$ & $(0.05)$ & $(0.40)$ \\
\hline \multicolumn{6}{|c|}{ Woman Education (re: Low Secondary or less) } \\
\hline \multirow[t]{2}{*}{ Tertiary } & $0.258^{* *}$ & & & & $0.223+$ \\
\hline & $(4.59)$ & & & & $(1.94)$ \\
\hline \multirow[t]{2}{*}{ Upper Secondary } & 0.062 & & & & -0.065 \\
\hline & $(1.41)$ & & & & $(0.95)$ \\
\hline
\end{tabular}


Adsera: The interplay of employment uncertainty and education in explaining second births in Europe

Table 3: (Continued)

\begin{tabular}{|c|c|c|c|c|c|}
\hline & $\begin{array}{l}\text { (1) } \\
\text { All }\end{array}$ & $\begin{array}{c}(2) \\
\text { Low } \\
\text { Educated }\end{array}$ & $\begin{array}{c}\text { (3) } \\
\text { Mid } \\
\text { Educated }\end{array}$ & $\begin{array}{c}\text { (4) } \\
\text { High } \\
\text { Educated }\end{array}$ & $\begin{array}{c}(5) \\
\text { Southern } \\
\text { Europe }\end{array}$ \\
\hline \multicolumn{6}{|c|}{ Partner Education (re: Low Secondary or less) } \\
\hline Tertiary & $\begin{array}{l}0.210^{\star *} \\
(4.25)\end{array}$ & $\begin{array}{l}-0.005 \\
(0.03)\end{array}$ & $\begin{array}{l}0.376^{* *} \\
(4.17)\end{array}$ & $\begin{array}{l}0.092 \\
(1.01)\end{array}$ & $\begin{array}{l}0.158 \\
(1.44)\end{array}$ \\
\hline Upper Secondary & $\begin{array}{l}0.002 \\
(0.06)\end{array}$ & $\begin{array}{l}0.021 \\
(0.23)\end{array}$ & $\begin{array}{l}0.065 \\
(1.07)\end{array}$ & $\begin{array}{l}-0.077 \\
(0.79)\end{array}$ & $\begin{array}{l}0.012 \\
(0.17)\end{array}$ \\
\hline \multicolumn{6}{|l|}{ Individual Level Variables } \\
\hline Work (t-7) & $\begin{array}{l}-0.184^{\star *} \\
(2.60)\end{array}$ & $\begin{array}{l}-0.404^{*} \\
(2.49)\end{array}$ & $\begin{array}{r}0.137 \\
(1.30)\end{array}$ & $\begin{array}{l}-0.235+ \\
(1.70)\end{array}$ & $\begin{array}{l}-0.267^{*} \\
(1.98)\end{array}$ \\
\hline Unemployed (t-7) & $\begin{array}{l}-0.139^{*} \\
(2.16)\end{array}$ & $\begin{array}{l}-0.177+ \\
(1.92)\end{array}$ & $\begin{array}{l}-0.110 \\
(1.23)\end{array}$ & $\begin{array}{l}-0.039 \\
(0.27)\end{array}$ & $\begin{array}{l}-0.142 \\
(1.64)+\end{array}$ \\
\hline $\begin{array}{l}\text { Public Sector } \\
\text { (if work }(\mathrm{t}-7)=1 \text { ) }\end{array}$ & $\begin{array}{l}0.304^{* *} \\
(4.83)\end{array}$ & $\begin{array}{l}0.387^{*} \\
(2.23)\end{array}$ & $\begin{array}{l}0.291^{* *} \\
(3.20)\end{array}$ & $\begin{array}{l}0.232^{*} \\
(2.24)\end{array}$ & $\begin{array}{l}0.253^{*} \\
(2.17)\end{array}$ \\
\hline $\begin{array}{l}\text { Part-Time } \\
\text { (if work }(\mathrm{t}-7)=1 \text { ) }\end{array}$ & $\begin{array}{l}0.130^{*} \\
(2.01)\end{array}$ & $\begin{array}{c}0.191 \\
(1.17)\end{array}$ & $\begin{array}{l}-0.109 \\
(1.04)\end{array}$ & $\begin{array}{l}0.300^{*} \\
(2.50)\end{array}$ & $\begin{array}{r}0.064 \\
(0.41)\end{array}$ \\
\hline $\begin{array}{l}\text { Self-Employed } \\
\text { (if work }(t-7)=1 \text { ) }\end{array}$ & $\begin{array}{c}0.082 \\
(0.78)\end{array}$ & $\begin{array}{l}0.357+ \\
(1.68)\end{array}$ & $\begin{array}{l}-0.318+ \\
(1.72)\end{array}$ & $\begin{array}{l}0.173 \\
(1.09)\end{array}$ & $\begin{array}{l}0.232 \\
(1.50)\end{array}$ \\
\hline $\begin{array}{l}\text { No Permanent Contract } \\
\text { (if work }(\mathrm{t}-7)=1 \text { ) }\end{array}$ & $\begin{array}{l}-0.194^{*} \\
(2.52)\end{array}$ & $\begin{array}{l}-0.156 \\
(0.96)\end{array}$ & $\begin{array}{l}-0.224+ \\
(1.87)\end{array}$ & $\begin{array}{l}-0.153 \\
(1.23)\end{array}$ & $\begin{array}{l}-0.188 \\
(1.44)\end{array}$ \\
\hline \multicolumn{6}{|l|}{ Work Income } \\
\hline Woman (t-7) & $\begin{array}{l}-0.017^{* *} \\
(3.40)\end{array}$ & $\begin{array}{l}-0.029^{*} \\
(2.20)\end{array}$ & $\begin{array}{l}-0.036^{* *} \\
(3.76)\end{array}$ & $\begin{array}{l}-0.004 \\
(0.83)\end{array}$ & $\begin{array}{l}-0.012 \\
(1.13)\end{array}$ \\
\hline Partner (t-7) & $\begin{array}{l}0.004^{*} \\
(2.02)\end{array}$ & $\begin{array}{l}0.006+ \\
(1.89)\end{array}$ & $\begin{array}{r}0.005 \\
(1.51)\end{array}$ & $\begin{array}{l}-0.002 \\
(0.64)\end{array}$ & $\begin{array}{r}0.007 \\
(1.58)\end{array}$ \\
\hline \multicolumn{6}{|l|}{ Country Level Variables } \\
\hline $\begin{array}{l}\text { Female Unemployment Rate } \\
(\mathrm{t}-12)\end{array}$ & $\begin{array}{l}-0.042+ \\
(1.82)\end{array}$ & $\begin{array}{l}-0.113^{* *} \\
(3.26)\end{array}$ & $\begin{array}{l}-0.006 \\
(0.14)\end{array}$ & $\begin{array}{l}-0.015 \\
(0.32)\end{array}$ & $\begin{array}{l}-0.047^{*} \\
(1.97)\end{array}$ \\
\hline Person-Month & 160,451 & 56,370 & 59,255 & 39,116 & 77,811 \\
\hline Subjects & 6,112 & 2,103 & 2,354 & 1,702 & 2,604 \\
\hline Failures & 2,493 & 725 & 931 & 744 & 853 \\
\hline
\end{tabular}

Note: The sample includes women in 12 European countries whose first births occurred on January 1992 or after. The coefficients are from Cox Proportional Hazard models. All columns include additional country level variables (share of government employment and its square, maternity leave, log income per capita) as well as year, monthly, and country dummies. Earnings are adjusted for differences in purchasing power and expressed in thousands of Euros. Exposure to the second birth starts at the time of the first birth. Robust $z$ statistics from errors clustered by duration since exposure in parentheses: + significant at $10 \%$; * significant at $5 \%$; ${ }^{*}$ significant at $1 \%$. All of the country variables are lagged one year and the individual variables are lagged seven months. 
Table 4: Transition to second births, employment conditions and very shortterm contracts in Europe (ECHP 1994-2000)

\begin{tabular}{lccccc}
\hline & $\mathbf{( 1 )}$ & $\begin{array}{c}(\mathbf{2}) \\
\text { Low } \\
\text { Educated }\end{array}$ & $\begin{array}{c}\mathbf{( 3 )} \\
\text { Mid } \\
\text { Educated }\end{array}$ & $\begin{array}{c}\mathbf{( 4 )} \\
\text { High } \\
\text { Educated }\end{array}$ & $\begin{array}{c}\text { Southern } \\
\text { Europe }\end{array}$ \\
\hline Individual Level Variables & All & & & & \\
Woman Employment (re: Inactive) & $-0.180^{* *}$ & $-0.391^{*}$ & 0.114 & -0.217 & $-0.261^{*}$ \\
Work (t-7) & $(2.58)$ & $(2.40)$ & $(1.11)$ & $(1.59)$ & $(2.01)$ \\
& $-0.139^{*}$ & $-0.177+$ & -0.109 & -0.041 & -0.142 \\
Unemployed (t-7) & $(2.16)$ & $(1.91)$ & $(1.22)$ & $(0.28)$ & $(1.64)^{+}$ \\
& $0.302^{* *}$ & $0.380^{*}$ & $0.294^{* *}$ & $0.232^{*}$ & $0.254^{*}$ \\
Public Sector & $(4.84)$ & $(2.19)$ & $(3.20)$ & $(2.27)$ & $(2.17)$ \\
(if work (t-7)=1) & $0.129^{*}$ & 0.189 & -0.108 & $0.303^{*}$ & 0.068 \\
Part-Time & $(2.00)$ & $(1.16)$ & $(1.03)$ & $(2.52)$ & $(0.44)$ \\
(if work (t-7)=1) & 0.078 & $0.357+$ & $-0.320+$ & 0.192 & 0.234 \\
Self-Employed & $(0.75)$ & $(1.68)$ & $(1.73)$ & $(1.21)$ & $(1.51)$ \\
(if work (t-7)=1) & $-0.223^{* *}$ & -0.204 & -0.159 & $-0.257+$ & $-0.228+$ \\
Very Short Contract & $(3.00)$ & $(1.28)$ & $(1.33)$ & $(1.86)$ & $(1.71)$ \\
(if work (t-7)=1) & & & & & \\
Country Level Variables & $-0.043+$ & $-0.114^{* *}$ & -0.006 & -0.014 & $-0.047^{*}$ \\
Female Unemployment Rate & $(1.83)$ & $(3.27)$ & $(0.15)$ & $(0.31)$ & $(1.98)$ \\
(t-12) & 160,451 & 56,370 & 59,255 & 39,116 & 77,811 \\
Person-Month & 6,112 & 2,103 & 2,354 & 1,702 & 2,604 \\
Subjects & 2,493 & 725 & 931 & 744 & 853 \\
Failures & & & & & \\
\hline
\end{tabular}

Note: The sample includes women in 12 European countries whose first births occurred on January 1992 or after. The coefficients are from Cox Proportional Hazard models. All columns include the same demographic characteristics in Table 3 (presence of a partner, marital status, education and work income of the woman and her partner, place of birth, sex of previous child, age at first birth), country-level variables (share of government employment and its square, maternity leave, log income per capita), as well as year, monthly, and country dummies. Exposure to the second birth starts at the time of the first birth. Robust $z$ statistics from errors clustered by duration since exposure in parentheses: + significant at $10 \%$; * significant at $5 \%$; ${ }^{* *}$ significant at $1 \%$. All of the country variables are lagged one year and the individual variables are lagged seven months.

When analyzing these results, it is important to remember that, given that labor supply and fertility are jointly determined, these estimated coefficients cannot be given a direct causal interpretation, since they may conceal some unobserved factors. Women who are unemployed and seeking work are, for example, less likely to have a child than economically inactive women, in part because they may be less willing or able to trade off work for further offspring. Similarly, highly educated mothers who intend to devote more time to raising their children are more likely to adjust their hours of work by requesting a part-time schedule than those more committed to their careers. Still, the 
estimates here provide information on the types of positions that are associated with faster transitions to second births.

Whether a personal experience of unemployment is associated with more or less fertility depends on either the lower opportunity cost faced by mothers in terms of wages relative to more prosperous times, or the negative income shock connected with unemployment (particularly if it is persistent). The coefficient of a woman's unemployment is negative and significant at $5 \%$ in column (1) of Tables 3 and 4 . The estimated hazard of having a second child among unemployed women is around $13 \%$ lower than that of inactive women. In columns (2) to (4), the unemployment coefficient is negative. However, it is only significant for the sample of women with low levels of education (column (2)). These women are likely to be the most vulnerable of all in an adverse labor market: within this group, those who do not drop off and continue to search for work are probably more in need of making "ends meet" than other women. Among Southern European women, the coefficient on unemployment is remarkably similar to that in column (1), though it is barely significant at $10 \%$, possibly due to the smaller sample size (column (5) in Tables 3 and 4). The weaker significance may also stem from the fact that, having postponed maternity the longest during this period, Southern European women who are already mothers constitute a more selected group in these countries than elsewhere in Europe.

Finally, as discussed in Section 2, the length of a worker's current contract is an indicator of how certain she is about her continuous employment, even after the birth of another child. In column (1) of Table 3, it is apparent that second births among European women without permanent jobs (of any contract length) happen significantly later than among those with permanent positions (the coefficient is significant at 5\%). The coefficient is negative for women in each educational group, but only marginally significant for middle-educated women (high school graduates). In column (5), among Southern Europeans, even if the coefficient is remarkably similar to that in column (1), it fails to reach statistical significance on its own. As noted before, this is likely related to both the small sample size and to the high selection of women in Southern Europe who were particularly cautious about securing a permanent position before giving birth in an extremely dualized market (Adam 1996; Gutierrez 2008).

Simulations using column (1) estimates indicate that women with non-permanent contracts in the private sector have the slowest transitions to second births among all mothers. Their estimated hazard rate is over $30 \%$ lower than that of inactive women. Keeping everything else at the mean, and allowing the type of employment to vary across individuals, simulations of estimates in column (1) indicate that $53.5 \%$ of women working in the private sector and holding a permanent contract, but only $42.5 \%$ of women in the private sector with non-permanent contracts, had given birth to a second child by the time their first child turned five. 
Moving beyond the distinction between temporary and permanent jobs, and in order to account for of extremely insecure jobs, Table 4 controls for contracts that are either very short (less than one year) or nonexistent. The coefficient of very short contracts is negative, larger than that for non-permanent contracts in Table 3, and significant (at 5\%) in column (1). In Southern European countries, it is significant at $10 \%$ (column (5)). Across educational groups, it is negative and sizable, but only significant among the most educated (columns (2) to (4)). As shown in Table 3, the share of highly educated workers in the OECD who held a temporary contract was close to $10 \%$, and one in five of all workers with non-permanent contracts was highly skilled. Some positions in Europe that lack formal contracts - or only have verbal contractsare, in many instances, prestigious professional jobs (e.g., lawyers, consulting) that are held by college graduates, and come with very demanding schedules.

Among the aggregate covariates, Tables 3 and 4 only display the coefficients on monthly female unemployment rates for the sake of brevity. The coefficients for the other country-level variables - as well as for the country, time, and monthly dummiesare available from the author. In column (1), the female unemployment rate prevailing in the country a year ago enters negatively in the model, but only at a $10 \%$ significance level. ${ }^{12}$ This confirms previous findings that second births are still affected by underlying economic uncertainty in the country (Ermisch 1988; Kravdal 2002). When the model is estimated separately by educational group, the coefficient for aggregate female unemployment is also negative, but it is only sizable and highly significant (at a $1 \%$ level) for the least educated (columns (2) to (4) in Tables 3 and 4). This goes handin-hand with the finding that, among all of the educational groups, a personal experience of unemployment deters the least educated the most from having a second child. Finally, in column (5), for the sample of Southern European countries where local unemployment grew the most during this period, the coefficient is of a similar size to that in the complete European sample, but it is more significant (at 5\%).

\section{Second births in Spain}

\subsection{Data and method}

The second part of the paper examines whether the relationships between economic conditions and timing of second births found in the European Union data hold with the

\footnotetext{
${ }^{12}$ In separate models available upon request, when country dummies are excluded, the coefficient on female monthly unemployment is significant at $1 \%$ level.
} 
same strength in Spain, the country with the highest employment shortages during the 1990s. As shown in Table 1, Spain was the country where both unemployment and the share of contracts of limited duration grew the most since the late 1980s. After a long period of stable and low unemployment rates during the 1960s and early 1970s, Spanish unemployment increased sharply from 1978 to 1985, and, subsequently, it remained high for many years (see Figures 2and 3). The increase was followed by the partial deregulation of the labor market in the mid-1980s, and a subsequent rise in temporary employment, particularly among women who were entering the labor market at that time, and young cohorts in general. As in other Southern European countries, the ratio of satisfaction with job security of those employed in temporary jobs relative to those in permanent jobs was very low during the 1990s (Table 1). Thus, employees holding a contract of limited duration were likely to perceive their future employment as uncertain.

I use the 2006 Spanish Fertility Survey to study how education and the economic conditions just described interact in explaining the transition to second births. The survey follows the guidelines of the Fertility Surveys from the United Nations. It was conducted during the period of April 17 to May 31, 2006. One woman was interviewed in each household. The total number of home interviews conducted was 10,000, and, of these women, close to 5,000 had at least one child and were included in the sample of analysis. The survey contains a rich set of variables on the members of the household and the complete fertility and marital histories of the women.

I use a proportional hazard model similar to that employed in Section 3 with the European data. I control for basic demographic background, such as the age at first birth, the sex of the first-born, the place of birth, the size of the municipality of residence, educational attainment, and the woman's number of siblings, as well as a set of 17 regional dummies. All of the models are stratified by birth cohort to account for potential changes in preferences across cohorts or other socioeconomic conditions idiosyncratic to each generation that may bias our results. ${ }^{13}$ Errors are clustered by region.

To measure the local economic environment faced by women, I use two indicators:

(1) Provincial quarterly unemployment rate in the province where a woman resides (out of 50 provinces); and

(2) Share of temporary employment over total employment in the country.

In addition to both the rate of unemployment and the share of temporary employment, some models include interactions of those two measures with the

${ }^{13}$ Cohorts are defined as 1. born before 1950; 2. 1950-59; 3. 1960-67; 4. 1968-75; 5. born after 1975. 
educational attainment of each woman. With these models, I examine whether economic conditions are connected to the timing to second births with different intensities across educational groups. The appendix presents the means and standard deviations of the independent variables for the sample of women in the analysis.

Local economic conditions are measured at two different points in time. The first set of estimates assigns to each woman the economic environment she faced three or four years after she potentially entered the labor market (either working or searching for a job). I measure these conditions at age 22 for those who did not go to college, and at age 26 for those who went on to tertiary education. My goal is to analyze whether women's initial labor market experiences - which may have had a lasting impact on the speed of household formation, women's future career prospects, and their expectations of the type of positions available to them (i.e., permanent versus temporary employment, or part-time versus full-time employment) - were related to second births.

In a second set of estimates, I split each woman's observation into multiple monthobservations from the month of her first birth, until either her second birth or the interview date. I introduce time-varying provincial unemployment rates and shares of permanent employment from the moment of the first birth onward to measure the underlying conditions at the time when the decision was made about whether or not to have a second child. As explained below, the results of the analysis of the Spanish data are consistent with those in Section 2. The coefficients of the relevant variables have the same sign in both sets of estimates: those with early labor market conditions and those with time-varying conditions since the first birth.

\subsection{Results}

Table 5 presents the models of transitions to second birth with economic conditions measured early in adult life. The model is estimated first for the whole sample, and then for all women born in 1950 or later, who were more likely than earlier cohorts to have participated in the labor market, and to have faced abrupt changes, both in the labor market and in social values, as they reached adulthood after the transition to democracy. Overall, the direction and size of all coefficients is remarkably stable across both samples, though the relevance of early labor market conditions increases for the younger sample. 
Adsera: The interplay of employment uncertainty and education in explaining second births in Europe

Table 5: Transitions to second birth, education and local economic conditions prevalent during early labor market experience (Spanish Fertility Survey 2006)

\begin{tabular}{|c|c|c|c|c|}
\hline & All & Born 1950+ & All & Born 1950+ \\
\hline \multicolumn{5}{|l|}{ Demographics } \\
\hline Age at First Birth & $\begin{array}{l}-0.003^{* *} \\
(8.11)\end{array}$ & $\begin{array}{l}-0.003^{* *} \\
(7.37)\end{array}$ & $\begin{array}{l}-0.003^{\star *} \\
(7.84)\end{array}$ & $\begin{array}{l}-0.003^{\star \star} \\
(7.26)\end{array}$ \\
\hline First Child boy & $\begin{array}{c}0.009 \\
(0.27)\end{array}$ & $\begin{array}{c}0.018 \\
(0.42)\end{array}$ & $\begin{array}{c}0.005 \\
(0.16)\end{array}$ & $\begin{array}{c}0.015 \\
(0.38)\end{array}$ \\
\hline Foreign-Born & $\begin{array}{l}-0.080 \\
(1.11)\end{array}$ & $\begin{array}{l}-0.044 \\
(0.57)\end{array}$ & $\begin{array}{l}-0.067 \\
(0.92)\end{array}$ & $\begin{array}{l}-0.040 \\
(0.55)\end{array}$ \\
\hline Woman Siblings & $\begin{array}{l}0.023^{* *} \\
(3.26)\end{array}$ & $\begin{array}{l}0.025^{* \star} \\
(2.69)\end{array}$ & $\begin{array}{l}0.023^{* *} \\
(3.22)\end{array}$ & $\begin{array}{l}0.024^{*} \\
(2.57)\end{array}$ \\
\hline \multicolumn{5}{|l|}{ Municipality (re: Town) } \\
\hline 400,000 or more & $\begin{array}{l}-0.206^{\star *} \\
(5.67)\end{array}$ & $\begin{array}{l}-0.184^{* *} \\
(3.71)\end{array}$ & $\begin{array}{l}-0.216^{* *} \\
(6.50)\end{array}$ & $\begin{array}{l}-0.192^{\star *} \\
(4.25)\end{array}$ \\
\hline $100,000-400,000$ & $\begin{array}{l}-0.001 \\
(0.02)\end{array}$ & $\begin{array}{r}0.050 \\
(0.77)\end{array}$ & $\begin{array}{l}-0.009 \\
(0.22)\end{array}$ & $\begin{array}{r}0.047 \\
(0.73)\end{array}$ \\
\hline $10,000-100,000$ & $\begin{array}{l}-0.059 \\
(1.49)\end{array}$ & $\begin{array}{l}-0.033 \\
(0.55)\end{array}$ & $\begin{array}{l}-0.063 \\
(1.59)\end{array}$ & $\begin{array}{l}-0.036 \\
(0.60)\end{array}$ \\
\hline \multicolumn{5}{|l|}{ Education (re: Low Secondary ) } \\
\hline Primary or less & $\begin{array}{c}0.042 \\
(1.55)\end{array}$ & $\begin{array}{c}0.056+ \\
(1.67)\end{array}$ & $\begin{array}{l}-0.035 \\
(0.93)\end{array}$ & $\begin{array}{l}-0.026 \\
(0.37)\end{array}$ \\
\hline High School/FP & $\begin{array}{c}0.046 \\
(0.86)\end{array}$ & $\begin{array}{c}0.012 \\
(0.21)\end{array}$ & $\begin{array}{c}0.071 \\
(0.94)\end{array}$ & $\begin{array}{l}-0.037 \\
(0.34)\end{array}$ \\
\hline College & $\begin{array}{l}0.385^{\star *} \\
(4.30)\end{array}$ & $\begin{array}{l}0.446^{\star *} \\
(4.38)\end{array}$ & $\begin{array}{c}0.139 \\
(1.15)\end{array}$ & $\begin{array}{c}0.248+ \\
(1.78)\end{array}$ \\
\hline \multicolumn{5}{|c|}{ Local Labor Market } \\
\hline \multicolumn{5}{|c|}{ Provincial Quarterly Unemployment Rate: } \\
\hline Unemp. Rate & $\begin{array}{l}-0.853^{*} \\
(1.97)\end{array}$ & $\begin{array}{l}-1.311^{* *} \\
(2.83)\end{array}$ & $\begin{array}{l}-1.112^{*} \\
(2.04)\end{array}$ & $\begin{array}{l}-1.524^{\star \star} \\
(3.22)\end{array}$ \\
\hline Unemp. Rate $x$ Primary or less & & & $\begin{array}{c}0.540 \\
(0.72)\end{array}$ & $\begin{array}{c}0.246 \\
(0.29)\end{array}$ \\
\hline Unemp. Rate x High School/FP & & & $\begin{array}{r}0.147 \\
(0.19)\end{array}$ & $\begin{array}{c}0.455 \\
(0.56)\end{array}$ \\
\hline Unemp. Rate $x$ College & & & $\begin{array}{c}1.119 \\
(1.26)\end{array}$ & $\begin{array}{c}0.735 \\
(0.93)\end{array}$ \\
\hline \multicolumn{5}{|l|}{ \%Temporary Employment } \\
\hline Temp. Emp. & $\begin{array}{l}-0.828^{*} \\
(1.98)\end{array}$ & $\begin{array}{l}-1.000^{*} \\
(2.22)\end{array}$ & $\begin{array}{l}-1.004+ \\
(1.88)\end{array}$ & $\begin{array}{l}-1.113^{*} \\
(2.07)\end{array}$ \\
\hline Temp. Emp x Primary or less & & & $\begin{array}{c}0.192 \\
(0.22)\end{array}$ & $\begin{array}{c}0.415 \\
(0.50)\end{array}$ \\
\hline Temp. Emp. x High School/FP & & & $\begin{array}{l}-0.239 \\
(0.36)\end{array}$ & $\begin{array}{l}-0.101 \\
(0.15)\end{array}$ \\
\hline Temp. Emp. $x$ College & & & $\begin{array}{r}0.624 \\
(1.18)\end{array}$ & $\begin{array}{c}0.434 \\
(0.81)\end{array}$ \\
\hline Subjects & 4,519 & 3,344 & 4,519 & 3,344 \\
\hline Failures & 3,290 & 2,282 & 3,290 & 2,282 \\
\hline
\end{tabular}

Note: The coefficients are from Cox Proportional Hazard models. Robust $z$ statistics in parentheses: + significant at $10 \%$; * significant at $5 \%$; ${ }^{* *}$ significant at $1 \%$. Errors clustered by 17 regions (Comunidad Autonoma). Dummies for Comunidades Autonomas included in estimates. Stratified by birth cohorts defined as 1. born before 1950; 2. 1950-59; 3. 1960-67; 4. 196875; 5 . born after 1975 . The results are robust to estimating primary education and less than primary education as separate variables, and to adding controls for home ownership and religious practice. 
Columns (1) and (2) present the basic model. Our two variables of interest show the expected sign, and are highly significant (at a 5\% level for the whole sample, and at a $1 \%$ level for the sample of those born in 1950 and later). Those women who lived in a province with relatively high unemployment early in their careers took more time to have a second child. Using estimates in column (1), and keeping everything else at the mean for the group, the proportion of women with low secondary education (less than high school) who would have had a second child eight years after their first varies from $70 \%$ if they faced a $5 \%$ unemployment rate in their early adulthood, to only $65 \%$ if that rate was $20 \%$ (in the upper range for the period under analysis). Using estimates in column (2), for cohorts born in 1950 and later, those proportions were $73 \%$ and $66 \%$, respectively. Similarly, those who experienced a labor market with a high prevalence of temporary employment in their young adulthood tended to postpone second births. The proportion of women with low secondary education who had had a second child by the eight birthday of their first-born fell from $71 \%$ if they faced a market in which only $5 \%$ of workers were temporary, to $63 \%$ if that same proportion was $30 \%$ (as in the most recent years in Spain). Thus, even if the decision to have a second child was not made at that point in life for many of them, the labor market conditions women faced in their early to mid-twenties, when they (or their partners) entered the labor market, appears to have had a long-lasting impact on their childbearing patterns. Having entered the market under adverse economic conditions seems to be associated with a postponement of motherhood, and with worse employment trajectories than might otherwise have been expected.

Columns (3) and (4) present the complete model, which includes interactions of economic conditions for each of the educational groups. The aim of these models is to find out whether there is some important interplay between the different aspects of economic uncertainty and educational status; that is, whether women with a given educational background respond more to either unemployment or to the prevalence of contracts of limited duration. In both models, the coefficients of provincial unemployment and the share of temporary contracts continue to enter negatively and significantly. The estimated coefficients of the interactive variables with both aggregate economic measures increase with the level of education (with the exception of temporary employment for high school graduates), indicating that, on average, the impact of those conditions is somewhat more moderate for the more educated. Even though none of the coefficients of the interactive variables is significant on its own, both the interactive variables and the levels of education and economic conditions are, in general, jointly significant. (Tests are available upon request.)

To better explain these results, Table 6 presents the predicted percentage of women who would have had a second child by the time their first child turned eight. The predictions are shown assuming different economic environments during the young 
adult years, and both for those with lower secondary school, and those with any type of college degree. All of the variables are set at the mean, except for the age at first birth, which is allowed to vary by educational group. Since in the model the economic conditions are entered not only linearly, but also interacted with education, the gap between educational groups as the underlying economic conditions vary does not remain constant. The top half of the table allows the provincial unemployment rate to vary from $5 \%$, to $10 \%$, and then $20 \%$; and sets the share of temporary employment at $14.5 \%$, the mean of the period. Whereas the share of college-educated women with a second child does not vary with unemployment, the share among those with lower secondary education falls from $69.6 \%$ to $63.5 \%$ when unemployment rises (Table 6 , first row). Unemployment has a strong effect on cohorts born in 1950 and later (Table 6 , second row). As unemployment rises from $5 \%$ to $20 \%$, the share of low educated women with a second child falls from $73.4 \%$ to only $65.2 \%$. Among college graduates, the percentage also falls, but only by four points, from $80.3 \%$ to $76.4 \%$. The bottom half of Table 6 simulates the impact of a change in the share of temporary employment from levels similar to those prevailing in the earlier years of the analysis, or around 5\% to $15 \%$; and then to the highest levels observed, or $30 \%$. Provincial unemployment is set at the mean of $11.5 \%$. The decrease in the share of second-time mothers as temporary employment becomes more common is now substantial for both education groups. It falls by nine points among the least educated, and by over three points among college graduates. Among those born after 1949, there is a 10-point drop for those with low secondary education, and a six-point drop among those with tertiary education.

Table 6: Proportion of second-time mothers by labor market conditions prevalent in early adulthood (models: Table 5 , columns $3 \& 4$ )

\begin{tabular}{|c|c|c|c|c|c|c|}
\hline \multicolumn{7}{|c|}{ Share of women with a Second Birth 8 years after $1^{\text {st }}$} \\
\hline & \multicolumn{6}{|c|}{ Provincial Unemployment Rate (Quarter) } \\
\hline & \multicolumn{2}{|c|}{$5 \%$} & \multicolumn{2}{|c|}{$10 \%$} & \multicolumn{2}{|c|}{$20 \%$} \\
\hline Education & Low Sec & College & Low Sec & College & Low Sec & College \\
\hline All & 69.6 & 74.0 & 67.6 & 74.0 & 63.5 & 74.1 \\
\hline \multirow[t]{3}{*}{ Born 1950+ } & 73.4 & 80.3 & 70.7 & 79.0 & 65.2 & 76.4 \\
\hline & \multicolumn{6}{|c|}{ Share Temporary Employment } \\
\hline & \multicolumn{2}{|c|}{$5 \%$} & \multicolumn{2}{|c|}{$15 \%$} & \multicolumn{2}{|c|}{$30 \%$} \\
\hline Education & Low Sec & College & Low Sec & College & Low Sec & College \\
\hline All & 70.4 & 75.3 & 66.8 & 74.0 & 61.3 & 72.0 \\
\hline Born $1950+$ & 73.7 & 80.7 & 69.7 & 78.5 & 63.6 & 75.0 \\
\hline
\end{tabular}

Note: The age at first birth is set at the mean of each education group, the birth cohort is set for those born 1960-67, and all other variables are set at the mean. The share of temporary employment is set at the mean when provincial unemployment is allowed to vary in the first two rows, and vice versa for the last two rows. Labor market conditions are measured at age 22 for individuals with high school or less, and at age 26 for individuals with tertiary education. 
To sum up, the results in Tables 5 and 6 show that, first, the negative association of adverse economic conditions and transitions to second births is very large among the least educated; and that, second, particularly among younger cohorts, an increase in the prevalence of contracts of limited duration is more detrimental to the childbearing plans of college graduate mothers than unemployment. It should be noted that the predicted differences shown in Table 6 would have been even larger had both economic conditions been allowed to vary jointly, as they did during the period. As shown in Figure 2, both the unemployment rate and the proportion of temporary contracts grew at the same time.

Table 7 uses the sample of person-month observations to include time-varying economic conditions from the time of the first birth until the second birth or the interview date. The models in columns (1) to (4) are estimated for the whole sample, and those in columns (5) to (8) for all women born in 1950 or after. The results are strikingly similar to those that employ economic conditions in early adulthood. Again, both the provincial unemployment rate and the share of temporary employment enter with a negative sign and are significant in all the models. Except for a couple of cases, the coefficients of the interactions of economic conditions with education are only jointly significant. College graduates are the least affected by bad times, but, in relative terms, they seem to have cared more about contractual instability than unemployment. Table 8 presents simulations of results in Table 7, columns (4) and (8) in a manner similar to those presented in Table 6 . The share of college graduates with a second child drops less than three points, from $77.2 \%$ to $74.5 \%$ as unemployment moves up from $5 \%$ to $20 \%$. Among the most recent cohorts, the drop is almost negligible. For the least educated, the decline of around six to seven points is similar in both samples. Again, the story is different when temporary employment instead of unemployment is allowed to vary. The share of women who decide to expand their families fluctuates significantly for both educational categories, and especially for later cohorts. In the last row of Table 8, the share of second births among the most educated moves from $86.1 \%$ to $78.3 \%$, and among those with only low secondary schooling, from $82.1 \%$ to $67.4 \%$, as the share of fixed-term contracts among the employed increases from 5\% to $30 \%$.

Among the controls included in the models in Tables 5 and 7, the estimates indicated that those who became mothers late, or those who lived in large cities, were less likely to have had a second child. Even though Spanish women delayed motherhood during this period, many still had at least one child around age 40 (Gonzalez and Jurado 2006). But, as expected, late motherhood was associated with lower completed fertility (Kohler, Billari, and Ortega 2002; Morgan 2003). Across education groups, those with college degrees who postponed motherhood the longest 
squeezed the first two births into a short period. ${ }^{14}$ In additional models not shown in the paper, results are robust to the inclusion of religious affiliation and type of housing, though the sample size is somewhat smaller due to missing information. ${ }^{15}$

Table 7: Transitions to second birth, education and time-varying local economic conditions since first birth (Spanish Fertility Survey 2006)

\begin{tabular}{|c|c|c|c|c|c|c|c|c|}
\hline & All & All & All & All & $\begin{array}{c}\text { Born } \\
1950+\end{array}$ & $\begin{array}{l}\text { Born } \\
1950+\end{array}$ & $\begin{array}{c}\text { Born } \\
1950+\end{array}$ & $\begin{array}{c}\text { Born } \\
1950+\end{array}$ \\
\hline \multicolumn{9}{|l|}{ Education (re: Low Secondary) } \\
\hline Primary or less & $\begin{array}{r}0.016 \\
(0.56)\end{array}$ & $\begin{array}{l}0.013 \\
(0.28)\end{array}$ & $\begin{array}{l}0.018 \\
(0.39)\end{array}$ & $\begin{array}{r}0.012 \\
(0.25)\end{array}$ & $\begin{array}{r}0.057 \\
(1.39)\end{array}$ & $\begin{array}{r}0.121 \\
(1.20)\end{array}$ & $\begin{array}{r}0.104 \\
(1.21)\end{array}$ & $\begin{array}{l}0.129 \\
(1.20)\end{array}$ \\
\hline High School/FP & $\begin{array}{r}0.067 \\
(1.61)\end{array}$ & $\begin{array}{l}0.188^{*} \\
(2.24)\end{array}$ & $\begin{array}{l}0.115+ \\
(1.74)\end{array}$ & $\begin{array}{l}0.190^{*} \\
(2.32)\end{array}$ & $\begin{array}{r}0.017 \\
(0.31)\end{array}$ & $\begin{array}{r}0.031 \\
(0.18)\end{array}$ & $\begin{array}{l}-0.071 \\
(0.55)\end{array}$ & $\begin{array}{l}-0.039 \\
(0.21)\end{array}$ \\
\hline College & $\begin{array}{l}0.320^{* *} \\
(3.95)\end{array}$ & $\begin{array}{c}0.138 \\
(1.23)\end{array}$ & $\begin{array}{c}0.118 \\
(1.05)\end{array}$ & $\begin{array}{c}0.075 \\
(0.60)\end{array}$ & $\begin{array}{l}0.379^{* *} \\
(4.39)\end{array}$ & $\begin{array}{c}0.225 \\
(1.37)\end{array}$ & $\begin{array}{c}0.207 \\
(1.20)\end{array}$ & $\begin{array}{c}0.110 \\
(0.51)\end{array}$ \\
\hline \multicolumn{9}{|c|}{ Provincial Quarterly Unemployment Rate: } \\
\hline Unemp. Rate & $\begin{array}{l}-1.393^{*} \\
(2.50)\end{array}$ & $\begin{array}{l}-1.388^{*} \\
(2.43)\end{array}$ & $\begin{array}{l}-1.312^{*} \\
(2.37)\end{array}$ & $\begin{array}{l}-1.291^{*} \\
(2.53)\end{array}$ & $\begin{array}{l}-1.284^{*} \\
(2.52)\end{array}$ & $\begin{array}{l}-1.263^{*} \\
(2.49)\end{array}$ & $\begin{array}{l}-1.205^{\star} \\
(2.36)\end{array}$ & $\begin{array}{l}-1.196^{*} \\
(2.53)\end{array}$ \\
\hline Unemp. Rate $x$ Primary or less & & $\begin{array}{l}-0.019 \\
(0.05)\end{array}$ & & $\begin{array}{c}0.175 \\
(0.34)\end{array}$ & & $\begin{array}{l}-0.419 \\
(0.72)\end{array}$ & & $\begin{array}{l}-0.220 \\
(0.32)\end{array}$ \\
\hline $\begin{array}{l}\text { Unemp. Rate x High } \\
\text { School/FP }\end{array}$ & & -0.826 & & -0.836 & & -0.084 & & -0.234 \\
\hline Unemp. Rate x College & & $\begin{array}{c}(1.32) \\
1.403+ \\
(1.78)\end{array}$ & & $\begin{array}{c}(1.12) \\
0.625 \\
(0.75)\end{array}$ & & $\begin{array}{c}(0.10) \\
0.952 \\
(0.96)\end{array}$ & & $\begin{array}{c}(0.27) \\
0.743 \\
(0.76)\end{array}$ \\
\hline \%Temporary Employment & & & & & & & & \\
\hline Temp. Emp. & $\begin{array}{l}-1.147^{\star *} \\
(2.97)\end{array}$ & $\begin{array}{l}-1.198^{* *} \\
(3.10)\end{array}$ & $\begin{array}{l}-1.259^{\star *} \\
(3.07)\end{array}$ & $\begin{array}{l}-1.263^{\star *} \\
(3.00)\end{array}$ & $\begin{array}{l}-1.468^{\star \star} \\
(3.87)\end{array}$ & $\begin{array}{l}-1.489^{* *} \\
(3.91)\end{array}$ & $\begin{array}{l}-1.541^{* *} \\
(3.94)\end{array}$ & $\begin{array}{l}-1.562^{* *} \\
(3.93)\end{array}$ \\
\hline Temp. Emp x Primary or less & & & $\begin{array}{l}-0.163 \\
(0.47)\end{array}$ & $\begin{array}{l}-0.258 \\
(0.59)\end{array}$ & & & $\begin{array}{l}-0.357 \\
(0.82)\end{array}$ & $\begin{array}{l}-0.303 \\
(0.61)\end{array}$ \\
\hline Temp. Emp. x High School/FP & & & $\begin{array}{l}-0.216 \\
(0.57)\end{array}$ & $\begin{array}{c}0.005 \\
(0.01)\end{array}$ & & & $\begin{array}{r}0.371 \\
(0.74)\end{array}$ & $\begin{array}{r}0.400 \\
(0.79)\end{array}$ \\
\hline Temp. Emp. x College & & & $\begin{array}{c}1.050^{*} \\
(2.45)\end{array}$ & $\begin{array}{c}0.855^{*} \\
(1.96)\end{array}$ & & & $\begin{array}{c}0.702 \\
(1.27)\end{array}$ & $\begin{array}{c}0.613 \\
(1.14)\end{array}$ \\
\hline Person-Month & 418,036 & 418,036 & 418,036 & 418,036 & 203,960 & 203,960 & 203,960 & 203,960 \\
\hline Subjects & 4,943 & 4,943 & 4,943 & 4,943 & 2,999 & 2,999 & 2,999 & 2,999 \\
\hline Failures & 3,553 & 3,553 & 3,553 & 3,553 & 1,965 & 1,965 & 1,965 & 1,965 \\
\hline
\end{tabular}

Note: The coefficients are from Cox Proportional Hazard models. All columns include the same demographic characteristics in Table 5. Robust $z$ statistics in parentheses: + significant at $10 \%$; ${ }^{*}$ significant at $5 \%$; ${ }^{* *}$ significant at $1 \%$. Errors clustered by 17 regions (Comunidad Autonoma). Dummies for Comunidades Autonomas also included in estimates. Stratified by birth cohorts defined as 1 . born before 1950; 2. 1950-59; 3. 1960-67; 4. 1968-75; 5. born after 1975. Results are robust to estimating primary education and less than primary education as separate variables.

\footnotetext{
${ }^{14}$ This finding has previously been partly attributed to selection in the European literature (Hoem and Hoem 1989; Kravdal 2001). It may also be related to economies of scale in raising children.

${ }^{15}$ Practicing Catholics followed by non-practicing Catholics transited the fastest to second births. Living in rental housing instead of owning the house was not relevant. Most of the selection arising from housing conditions was more important in the transition to motherhood or leaving the parental home rather than for second births. (Holdsworth and Irazoqui-Solda 2002).
} 
Table 8: $\quad$ Proportion of second-time mothers by varying labor market conditions since their first birth (models: Table 7, columns 4 \& 8)

\begin{tabular}{|c|c|c|c|c|c|c|}
\hline \multicolumn{7}{|c|}{ Share of women with a Second Birth 8 years after $1^{\text {st }}$} \\
\hline \multirow[b]{3}{*}{ Education } & \multicolumn{6}{|c|}{ Provincial Unemployment Rate (Quarter) } \\
\hline & \multicolumn{2}{|c|}{$5 \%$} & \multicolumn{2}{|c|}{$10 \%$} & \multicolumn{2}{|c|}{$20 \%$} \\
\hline & Low Sec & College & Low Sec & College & Low Sec & College \\
\hline All & 74.5 & 77.2 & 72.2 & 76.3 & 67.6 & 74.5 \\
\hline \multirow[t]{3}{*}{ Born 1950+ } & 77.9 & 82.3 & 75.8 & 82.0 & 71.5 & 81.2 \\
\hline & \multicolumn{6}{|c|}{ Share Temporary Employment } \\
\hline & \multicolumn{2}{|c|}{$5 \%$} & \multicolumn{2}{|c|}{$15 \%$} & \multicolumn{2}{|c|}{$30 \%$} \\
\hline Education & Low Sec & College & Low Sec & College & Low Sec & College \\
\hline All & 76.6 & 78.2 & 72.4 & 77.0 & 65.8 & 75.2 \\
\hline Born 1950+ & 82.1 & 86.1 & 76.6 & 83.2 & 67.4 & 78.3 \\
\hline
\end{tabular}

Note: The age at the first birth is set at the mean of each education group, the birth cohort is set for those born 1960-67, and all of the other variables are set at the mean. The share of temporary employment is set at the mean when provincial unemployment is allowed to vary in the first two rows, and vice versa for the last two rows.

\section{Discussion: Employment uncertainty and education}

This paper analyzes how labor market instability due to rising unemployment and the high prevalence of contracts of limited duration affect the decision to have a second child among women of different educational groups. To this end, I first use ECHP data on women from 12 European countries to estimate models of the timing of a second birth that include as covariates time-varying measures of aggregate market conditions in each woman's country, as well as her individual labor market history. Second, I estimate similar models with women from the Spanish Fertility Survey 2006. Market instability is measured by the levels of provincial unemployment and temporality faced by women, either earlier in their careers or since the birth of their first child. Both analyses show that unemployment and employment insecurity embedded in contracts of limited duration are powerfully connected to those decisions. Postponement of a second child is significant in countries with high unemployment and among the unemployed. Women who have temporary contracts, or who live in a context in which those contracts are highly prevalent, are shown to be less likely to give birth to a second child.

Economic uncertainty and educational levels are found to interact in [two] main ways. First, even though unemployment is negatively associated with transitions to second births among all women, those with low levels of education (less than high school or similar) are the most responsive to changes in both aggregate and individual unemployment conditions, both in the European and in the Spanish data. The predictions in Tables 6 and 8 show slow transitions to second births among low educated Spaniards who face an adverse labor market, whereas the impact of 
unemployment for highly educated women is fairly small. In Tables 3 and 4, low educated women across Europe who are unemployed have significantly slower transitions to a second child than those who are inactive or work for the public sector. These coefficients are not significant on their own for higher educational categories. As already discussed, the estimated coefficients in the models cannot be given a causal interpretation. However, they are very relevant in showing that, among the least educated who decide (and need) to continue to search for a job (thus remaining in the ranks of the unemployed) instead of dropping out of the market, the likelihood of a second birth is lower than for those who choose to remain inactive. In the 1999 Spanish Fertility Survey, economic constraints appear as one of the top reasons for restricting fertility among women who report a gap between their preferred family size and their actual fertility. The need to work outside of the home and the unemployment of either the woman or her partner is also ranked high (Adsera 2006). It is important to remember that these women are already mothers, and that the impact of unemployment is found to be particularly acute for delaying motherhood altogether (Ahn and Mira 2001; Adsera 2005, 2011). Thus, the sample of women we observed is likely to be somewhat positively selected, since these women have already passed the first hurdle by becoming mothers.

A second important finding is that the increase of temporality in employment hampers second births for women across all educational groups, and not only for the least educated. The estimated coefficients in Tables 3 and 4 are negative, large, and of reasonably similar sizes in the three skill-specific columns, but they are only significant among the middle-educated in Table 3 for any temporary contract, and among the most educated in Table 4 for very short contracts. Relative to unemployment, a high prevalence of non-permanent positions seems to be most relevant for middle or highly educated women. The predicted percentage of second-time mothers among collegeeducated women, in Tables 6 and 8 , varies substantially, along with the prevalence of fixed-term contracts in the country, both in their early adulthood and since the birth of their first child. These findings indicate that there is a general agreement on the desirable characteristics of a labor market, but that those characteristics may be ranked somewhat differently by individuals, depending on their need to bring an extra paycheck to the home, and on their ability to wait for a good job match (and to absorb the search costs). By contrast, the goal of attaining a permanent position with secure and generous benefits may be less urgent to some women with narrow market options than bringing some additional income to the household. More educated women may have higher expectations and be ready (and able) to wait for a job that offers greater security.

A final point worth highlighting is that, in Tables 3 and 4, the specific length of the contract is significant among those with at least high secondary education. For the 
middle educated (high school graduates), temporality matters in general. For the college graduates, very short-term contracts or the lack thereof (even in professional jobs) put them in a situation that they may see as too precarious for having a second child in the near future. This finding is not completely surprising since, as shown in Table 2, the share of highly educated workers in the OECD who hold a temporary contract is not negligible, and $20 \%$ of all workers with non-permanent contracts are highly skilled. Those workers are, however, more likely to get a permanent contract. The OECD (2002) report shows that mobility into permanent jobs is highest among middle to highly educated 25-to-34-year-olds who have been continuously employed during at least the last five years. Thus, postponing childbearing until a permanent job has been secured seems a rational strategy. Conversely, less educated workers in Europe (with the exception of Austria and the UK) face more obstacles to converting their jobs into permanent positions, and are more likely to become unemployed than workers with more education. This is particularly true in Southern Europe, where low educated workers are $17 \%-24 \%$ less likely to move to a permanent job (OECD 2002).

\section{Acknowledgements}

I would like to thank seminar participants in "Employment Uncertainty and Family Dynamics" in Berlin, July 2009; two anonymous referees for their comments; and German Rodriguez for statistical assistance. 


\section{References}

Aassve, F.A., Billari, C.F., and Ongaro, F. (2001). The impact of income and occupational status on leaving home: Evidence from the Italian ECHP sample. Labour 15(3): 501-529. doi:10.1111/1467-9914.00175.

Adam, P. (1996). Mothers in an insider-outsider economy: The puzzle of Spain. Journal of Population Economics 9(3): 301-323. doi:10.1007/BF00176690.

Addison, J.T. and Teixeira, P. (2003). The economics of employment protection. Journal of Labor Research 24(1): 85-128. doi:10.1007/s12122-003-1031-0.

Adsera, A. (2005). Vanishing children: From high unemployment to low fertility in developed countries. American Economic Review Papers and Proceedings 95(2): 198-193.

Adsera, A. (2006). An economic analysis of the gap between desired and actual fertility: The case of Spain. Review of Economics of the Household 4(1): 75-95. doi:10.1007/s11150-005-6698-y.

Adsera, A. (2011). Where are the babies? Labor market conditions and fertility in Europe. European Journal of Population 21(1): 1-32. doi:10.1007/s10680-0109222-x.

Ahn, N. and Mira, P. (2001). Job bust, baby bust? Evidence from Spain. Journal of Population Economics 14(3): 505-521. doi:10.1007/s001480100093.

Andersson, G., Kreyenfeld, M., and Mika, T. (2009). Welfare state context, female earnings and childbearing. Max Planck Institute for Demographic Research. (MPIDR Working Paper 2009-026).

Azmat, G., Guell, M., and Manning, A. (2006). Gender gaps in unemployment rates in OECD countries. Journal of Labor Economics 24(1): 1-37. doi:10.1086/497817.

Becker, G. (1981). A treatise on the family. Cambridge, Mass: Harvard University Press.

Bertola, G., Blau, F., and Kahn, L. (2002). Labor market institutions and demographic employment patterns. Cambridge, MA: National Bureau of Economic Research. (Working Paper No. W9043).

Blanchard, O. and Landier, A. (2002). The perverse effects of partial labour market reform: Fixed-term contracts in France. Economic Journal 112(480): F214F244. doi:10.1111/1468-0297.00047. 
Blossfeld, H.-P., Klijzing, E., Mills, M., and Kurz, K. (2005). Globalization, uncertainty and youth in society. Oxford: Routledge.

Bongaarts, J. (2002). The end of the fertility transition in the developed world. Population and Development Review 28(3): 419-443. doi:10.1111/j.17284457.2002.00419.x.

Booth, A.J., Dolado, J., and Frank, J. (2002). Symposium on temporary work: Introduction. Economic Journal 112(480): F181-F188. doi:10.1111/14680297.00044.

Booth, A.J., Francesconi, M., and Frank, J. (2002). Temporary jobs: Stepping stones or dead ends? Economic Journal 112(480): F189-F213. doi:10.1111/14680297.00043 .

Browning, M. (1992). Children and household economic behavior. Journal of Economic Literature 30(3): 1414-1475.

Butz, W. and Ward, M. (1980). Completed fertility and its timing. Journal of Political Economy 88(5): 917-940. doi:10.1086/260914.

De Cooman, E., Ermisch, J., and Joshi, H. (1987). The next birth and the labour market: A dynamic model of births in England and Wales. Population Studies 41(2): 237-268. doi:10.1080/0032472031000142786.

Dolado, J.J., García-Serrano, C., and Jimeno, J.F. (2002). Drawing lessons from the boom of temporary jobs in Spain. The Economic Journal 112(480): 270-295. doi:10.1111/1468-0297.00048.

Ehling, M. and Rendtel, U. (2004). Research results of Chintex - summary and conclusions. In: The change from input harmonization to ex-post harmonization in national samples of the European community household panel (Chintex). Federal Statistical Office of Germany.

Ermisch, J. (1988). Econometric analysis of birth rate dynamics in Britain. The Journal of Human Resources 23(4): 563-576. doi:10.2307/145814.

Esping-Andersen, G. (1999). Social foundations of postindustrial economies. Oxford: Oxford University Press. doi:10.1093/0198742002.001.0001.

Galor, O. and Weil, D. (1996). The gender gap, fertility and growth. American Economic Review 86: 374-387. 
Gauthier, A.H. (2007). The impact of family policies on fertility in industrialized countries: A review of the literature. Population Research and Policy Review 26(3): 323-346. doi:10.1007/s11113-007-9033-x.

González, M.J. and Jurado, T. (2006). Remaining childless in affluent economies: A comparison of France, West Germany, Italy and Spain. European Journal of Population 22(4): 317-352. doi:10.1007/s10680-006-9000-y.

Gutierrez-Domenech, M. (2008). The impact of the labour market on the timing of marriage and births in Spain. Journal of Population Economics 21(1): 83-110. doi:10.1007/s00148-005-0041-z.

Hoem, B. (2000). Entry into motherhood: The influence of economic factors on the rise and fall in fertility, 1986-1997. Demographic Research 2(4). doi:10.4054/ DemRes.2000.2.4.

Hoem, B. and Hoem, J. (1989). The impact of women's employment on second and third births in modern Sweden. Population Studies 43(1): 47-67. doi: $10.1080 / 0032472031000143846$.

Holdsworth, C. and Irazoqui-Solda, M. (2002). First housing moves in Spain: An analysis of leaving home and first housing acquisition. European Journal of Population 18(1): 1-19. doi:10.1023/A:1013831818482.

Holmlund, B., Kolm, A.-S., and Storrie, D. (2002). Temporary jobs in turbulent times: The Swedish experience. The Economic Journal 112(480): 245-269. doi:10.1111/1468-0297.00042.

Kohler, H.-P., Billari, F.C., and Ortega, J.A. (2002). The emergence of lowest-low fertility in Europe during the 1990s. Population and Development Review 28(4): 599-639. doi:10.1111/j.1728-4457.2002.00641.x.

Kravdal, O. (2001). The high fertility of college educated women in Norway. Demographic Research 5(6): 187-216. doi:10.4054/DemRes.2001.5.6.

Kravdal, O. (2002). The impact of individual and aggregate unemployment on fertility in Norway. Demographic Research 6(10): 263-294. doi:10.4054/DemRes.2002. 6.10 .

Kreyenfeld, M. (2009). Uncertainties in female employment careers and the postponement of parenthood in Germany. European Sociological Review 26(3): 351-366. doi:10.1093/esr/jcp026. 
Lesthaeghe, R. and Surkyn, J. (1988). Cultural dynamics and economic theories of fertility change. Population and Development Review 14(1): 1-45. doi:10.2307/ 1972499.

Lin, D.Y. and Wei, L.J. (1989). The robust inference of the Cox Proportional Hazards model. Journal of the American Statistical Association 84(408): 1074-1078. doi:10.2307/2290085.

Morgan, S.P. (2003). Low fertility in the twenty-first century. Demography 40(4): 589603. doi:10.1353/dem.2003.0037.

Murphy, M. (1992). Economic models of fertility in post-war Britain: A conceptual and statistical re-interpretation. Population Studies 46(2): 235-258. doi:10.1080/ 0032472031000146216.

Nicoletti, C. and Peracchi, F. (2002). A cross-country comparison of survey nonparticipation in the ECHP. (ISER Working Paper 2002-32).

OECD (2002). Chapter 3: Taking the measure of temporary employment. In: OECD Employment Outlook. Paris: OECD.

OECD (2004). Chapter 2: Employment protection regulation and labour market performance. In: OECD Employment Outlook. Paris: OECD.

Saint-Paul, G. (2000). Flexibility vs. rigidity: Does Spain have the worst of both worlds? IZA Discussion paper 144.

Sobotka, T. (2004). Is lowest-low fertility in Europe explained by the postponement of childbearing? Population and Development Review 30(2): 195-220. doi:10.1111/ j.1728-4457.2004.010_1.x.

Sobotka, T., Skirbekk, V., and Philipov, D. (2010). Economic recession and fertility in the developed world. A literature review, Research Note (produced for the European Commission). Vienna, Austria: Vienna Institute of Demography.

Speder, Z. and Kapitany, B. (2009). How are time-dependent childbearing intentions realized? Realization, postponement, abandonment, bringing forward. European Journal of Population 25(4): 503-523. doi:10.1007/s10680-009-9189-7.

US Department of Health and Human Services (2002-2010). Social Security Programs throughout the World. Washington DC. http://www.ssa.gov/policy/ docs/progdesc/ssptw/. 


\section{Appendix}

Table A1: Means of variables in Spanish Fertility Survey, 2006

\begin{tabular}{lcc}
\hline Variable & Mean & Std.Dev. \\
\hline Demographics & 309 & 57 \\
Age at First Birth (in months) & 0.53 & 0.50 \\
First Child Boy & 0.07 & 0.26 \\
Foreign-Born & 3.11 & 2.31 \\
N. Siblings of Woman & & \\
Municipality (ref. town) & 0.12 & 0.32 \\
400,000 or more & 0.26 & 0.44 \\
100,000-400,000 & 0.33 & 0.47 \\
10,000-100,000 & & \\
Education (ref. low secondary) & 0.29 & 0.46 \\
Primary or less & 0.19 & 0.39 \\
High School/FP & 0.15 & 0.35 \\
College & & \\
Early Labor Market Conditions & 0.12 & 0.09 \\
Provincial Quarterly Unemp. Rate & 0.15 & 0.13 \\
\% Temporary Employment & &
\end{tabular}

